Cheryl Trepanier

University of Alberta, Edmonton, AB, CANADA

Ali Shiri

University of Alberta, Edmonton, AB, CANADA

Toni Samek

University of Alberta, Edmonton, AB, CANADA

\title{
ETHICS: TO DO OR NOT TO DO?
}

\section{Exploring frameworks for library and information ethics and data ethics}

\begin{abstract}
:
This paper compares the 2012 International Federation of Library Associations and Institutions' Code of Ethics for Librarians and Other Information Workers and the 2013 Data Science Association's Data Science Code of Professional Conduct and discusses the disjuncture and related considerations that might strengthen practical understandings of the implications of ethics in library and information professional practice. This paper cautions against conflating a data scientist's ethical framework with those of the traditional librarian and supports the development of a more robust framework for library and information ethics and a more comprehensive and inclusive framework for thinking about and conceptualizing data ethics.
\end{abstract}

\section{Introduction}

Data is a multi-faceted and complex concept that makes data studies and data research interesting, challenging and interdisciplinary. Evidence of the multifaceted nature of data can be found in prior research (Shiri 2014) that delineates the different aspects and facets of data, such as by creation, by nature, by context, by creator, by processing, by publication, by structure, by format, and by access. A depiction of various data facets can be found in Figure 1. 


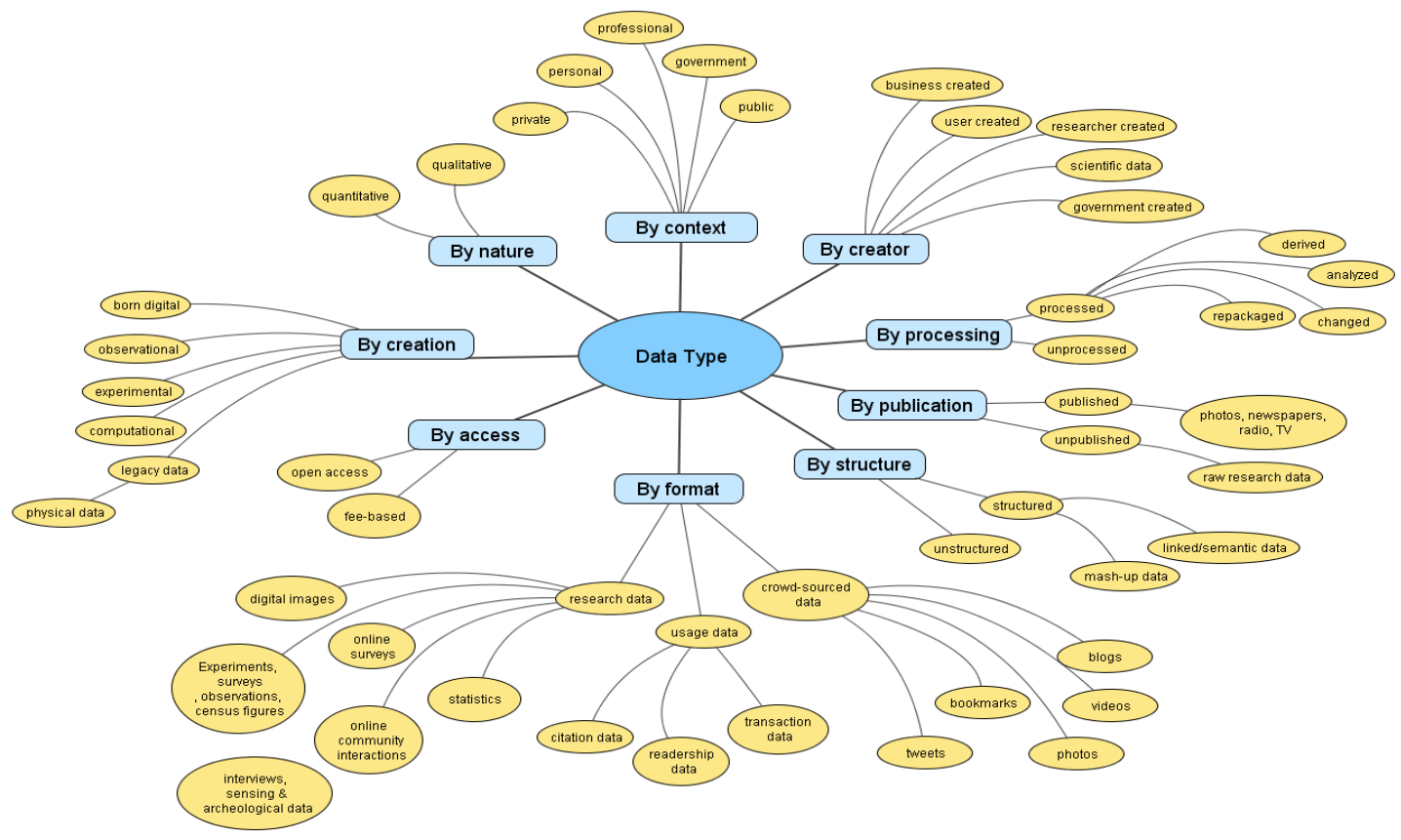

Figure 1. Facets of data

It is vital for the library and information science community to provide coherent and critical perspectives of data science, data research and data studies in order to offer a framework of thought, research and practice. Given the long-standing contribution of information science to the conceptualization and understanding of the nature of data, information and knowledge, it is reasonable to assume that disciplinary traditions and methodological and theoretical approaches and frameworks have the potential to shed light on the new ways of addressing, researching and making use of data in a wide variety of activities, disciplines and contexts. This kind of research may call for cross-disciplinary examination of the ways in which the data science community and the library and information studies community conceptualize, address and operationalize ethics.

In his paper entitled "Information Ethics in the Twenty First Century", Paul Sturges posits information ethics, in the context of discourse of information science, "has tended to grow out of discussion of the ethics of librarianship" (Sturges 2009, 242). He explains this "professional convergence, driven by the growth of the Internet and digital access, shifts emphasis, but there is a core of intellectual freedom issues, privacy and secrecy, concerns with social equity and justice and matters regarding ownership of information that show differing faces across all of the domains" (Sturges 2009, 242). More recently, Luciano Floridi and Mariarosaria Taddeo's preprint entitled "What is Data Ethics?" discusses how data ethics has emerged in the broader ethics 
ethos, most recently building on computer and information ethics. They suggest "the shift from information ethics to data ethics is probably more semantic than conceptual" (Floridi and Taddeo 2016, 3). In both scenarios, they note, interest is in moral dimensions and problems and corresponding practices and solutions (Floridi and Taddeo 2016, 3). This angle generated our interest in professional codes and labour rights and responsibilities.

This paper builds on previous scholarship and examines the emergence of data ethics through a library and information ethics perspective. The main objectives of this paper are to provide a comparison of the 2012 International Federation of Library Associations and Institutions (IFLA)'s Code of Ethics for Librarians and Other Information Workers and the 2013 Data Science Association (DSA)'s Data Science Code of Professional Conduct and to discuss the disjuncture and related considerations that might strengthen practical understandings of the implications of ethics in library and information professional practice. This kind of comparative content analysis grounds ethical considerations in practical terms and ties into a myriad of professional challenges in critical decision-making for contemporary library and information workers. Examples may include ethical dilemmas presented by access to information, the right to know, the right to be forgotten, privacy and confidentiality, intellectual property, and data protection. With the emergence of data ethics, and the quest to explore an ethos of library and information ethics to data ethics, this paper cautions against conflating a data scientist's ethical framework with those of librarians and other information workers. The paper also reinforces the need for attention to librarians and other information workers, as well as data scientists, in labour studies. As a disclaimer, this short and focused paper is a treatment of ethics, but not justice, information justice or data justice.

The comparison of the two codes is a valuable experimental endeavour for identifying and informing critical considerations and nuances in exploring data ethics vs. library ethics. However, it is a limited scholarly enterprise focused on just two different documents. Professional decision-making may be guided by codes of ethics, but not necessarily enforced, as is the case with IFLA's code. Codes of conduct, on the other hand, especially those imposed by an employer, may look relatively different and may be enforceable within labour terms.

\section{Methodology}

This paper uses a comparative content analysis that maps the 2013 DSA's Data Science Code of Professional Conduct to the 2012 IFLA's Code of Ethics for Librarians and Other Information Workers. As the first-existing code and to examine the position that information ethics has grown from the emergence of library ethics, the IFLA code provided the basis against which the DSA Code was examined on a clause-by-clause basis for similarities and differences with the 
IFLA code, identifying overlaps and gaps between the two. For a full comparison on a clause-byclause basis, see Appendix A.

Table 1 provides a comparative overview of the six thematic sections featured in IFLA's Code of Ethics for Librarians and Other Information Workers and the eight rules introduced by the Data Science Code of Professional Conduct.

\begin{tabular}{|c|c|}
\hline $\begin{array}{l}2012 \text { IFLA Code of Ethics for Librarians } \\
\text { and Other Information Workers }\end{array}$ & $\begin{array}{l}2013 \text { DSA Data Science Code of Professional } \\
\text { Conduct }\end{array}$ \\
\hline $\begin{array}{ll}\text { - } & \text { access to information } \\
\text { - } & \text { responsibilities towards individuals and } \\
& \text { society } \\
\text { - } & \text { privacy, secrecy and transparency } \\
\text { - } & \text { open access and intellectual property } \\
\text { - } & \text { neutrality, personal integrity and } \\
\text { professional skills } \\
\text { - } \\
\text { colleague and employer/employee } \\
\text { relationship }\end{array}$ & $\begin{array}{l}\text { - } \text { competence } \\
\text { - } \text { scope of data science professional } \\
\text { services between client and data } \\
\text { scientist } \\
\text { - } \quad \text { communication with clients } \\
\text { - confidential information } \\
\text { - } \text { duties to prospective client } \\
\text { - data science evidence, quality of data } \\
\text { - } \begin{array}{l}\text { and quality of evidence } \\
\text { scientaining integrity of the data }\end{array} \\
\text { scofession and misconduct }\end{array}$ \\
\hline
\end{tabular}

Table 1. Comparison of code of ethics and code of conduct

Using the range of elements found in these frameworks, the comparative content analysis data was furthered analyzed for commonalities and differences. The analysis shows some overlaps by concept (e.g., professionalism, confidentiality). Following on Floridi and Taddeo's paper, mutual attention to these concepts shows how emergent data ethics can bridge from library and information ethics in terms of categories on professional documents. We also identified critical content gaps. For example, free speech in the workplace and whistleblowing, two significant labour considerations in the twenty-first century on a global scale, only appear in the IFLA code. Following on Sturges, this illustrates an incomplete flow of library and information ethics forward into data ethics.

\section{Analysis and Discussion}

Our analysis concentrates on the differences between the two codes because they are significant. The discussion is organized into key themes that emerged in the literature and in the analysis, and which tease out some important differences in understanding the professional work of data scientists and librarians and other information workers. These are: data vs. information; clients 
vs. users; private vs. public; exclusivity vs. inclusivity; information as a strategic asset vs. as a public good; and, cautionary vs. permissive approaches to professionalism.

\subsection{Data vs. information}

The DSA defines data as "a tangible or electronic record of raw (factual or non-factual) information (as measurements, statistics or information in numerical form that can be digitally transmitted or processed) used as a basis for reasoning, discussion, or calculation and must be processed or analyzed to be meaningful." According to the DSA, data science means "the scientific study of the creation, validation and transformation of data to create meaning". Data scientist, in DSA terms, refers to "a professional who uses scientific methods to liberate and create meaning from raw data”.

Interestingly, the DSA Code of Professional Conduct defines 'data' and 'knowledge' but not information. Knowledge is information backed by scientific evidence that creates meaning. In this realm, it is the role of the scientist to make meaning of raw data that is available; the client is dependent on the manipulation and interpretation of the scientist. In the library realm, however, librarians and other information workers provide access to final form information, including helping to find/source it, but the user is responsible for interpreting the meaning that is attributable to it. The data scientist provides a 'value-added' service to data; librarians and other information workers connect the user to data/information, but do not enhance/interpret it in any way - in fact, are expected to refrain from judgement.

\subsection{Clients vs. users}

IFLA/librarians use the term 'users'; the data science code refers to 'clients'. What, if anything, does this imply about fundamental differences in duty, confidentiality, and commodification of underlying data/information? The broader literature suggests 'customer service' and 'valueadded' are contemporary phrases that are in common use in both publicly funded and not publicly funded library and information organizations and settings.

\subsection{Private vs. public}

The data scientist is dealing with datasets that are not necessarily publically available, often private (this may shift as more research data is available with open access or potentially hacked). While confidentiality of information is conditional for a data scientist, librarians and other information workers are accessing information that is 'publically' available (or within the realm of the institute under consideration), and therefore do not have a confidentiality issue with the information itself (although there is a responsibility not to identify the user with the information). 


\subsection{Exclusivity vs. Inclusivity}

A significant portion of the DSA Code of Professional Conduct is dedicated to conflict of interest provisions. The data scientist is in a contractual relationship (which may be explicit or implicit), which may specify or impose a level of exclusivity. The DSA code further imposes exclusivity provisions. A librarian (especially in the traditional setting where access to information is not exclusive) is not subject to such restraints - in fact, acts as a public resource connecting all users, on an equitable basis, to any information that is available. The librarian is not subject to conflict of interest concerns.

\subsection{Strategic Asset vs. Public Good}

In the data science world, data may be owned and capitalized upon for profit-maximization; the scientist's services are a value-added commodity to be marketed. Ownership of specific data and/or the ability to manipulate can be a strategic asset to be offered to the marketplace. Librarianship advocates for universal access whenever possible.

\subsection{Cautionary vs. Permissive}

The data scientist has a duty of care as a professional; within the DSA code, the data scientist is held to the standard of reasonableness and the code provides a number of specifics about how one's duties should be executed. Failure to adhere to the code is considered professional misconduct. There is an element of protection of the integrity of the profession implicitly imposed on the data scientist. Reflected in the wording of the IFLA code, librarianship (arguably) does not operate as a true and 'regulated' profession. There are no competency requirements to represent oneself as a librarian. Librarians and other information workers do not have an enforceable duty, nor can be subject to sanctions or expulsion. (Although this could occur within specific employment contracts.)

With no enforcement authority, this reduces the IFLA code to persuasion and consensus building and aspirational rhetoric. For context, the world's oldest and largest library association, the American Library Association (ALA), developed a statement entitled Questions \& Answers on Enforcement of the Code of Ethics. It states:

As a voluntary membership organization, ALA does not enforce the Code of Ethics for a variety of reasons. As a non-licensing professional society, the ALA would have two possible actions in response to a violation of the Code of Ethics: Suspend or expel a member from membership, or admonish or censure an individual or institution, publicly or privately.” (Questions \& Answers 2009) 


\section{Key Findings}

The emergent gaps between the two codes expose key differences between the professional work of data scientists and librarians and other information workers. Particularly notable is the impact that the expectation of advocacy plays in distinguishing between the two.

Librarians and other information workers are urged to strive for transparency of information. This directive teases out an active advocacy responsibility that is not apparent in the DSA code and this is not surprising. Directives around advocacy in a code of conduct would have to be very prescriptive. The 2013 Library and Archives Canada, Code of Conduct: Values and Ethics originally framed librarians and archivists speaking at conferences and teaching as so-called "high risk" activities (McGrath 2013).

The combination of no enforcement authority coupled with the expectation of advocacy results in vulnerability for librarians and other information workers who go out on a limb with their commitment to professional ethics. As an example, librarians and other information workers who express their intellectual freedom through workplace speech or engage in whistleblowing as encouraged by the IFLA rhetoric could actually put themselves in peril with their local communities and administrations. A code of ethics without a defense structure is debilitating. The restrictive nature of the DSA's Code of Professional Conduct does not invite this problem.

The IFLA code is framed as permissive by listing things one is encouraged to do. On the other hand, the DSA code is framed as cautionary by listing things one should refrain from doing. IFLA encourages non-enforceable compliance as a positive act. DSA discourages noncompliance by making it grounds for misconduct, a negative act. In the specific context of our very small-scaled analysis, we would suggest we do not see data ethics as automatically growing out of library and information ethics. What we can see, though, is problematic for an unregulated profession. And this raises important questions about violations of ethics and related due process. Implications for this work transcend an interest in data and extend into scholarship in the professions and labour studies.

\section{Conclusion}

People with an interest in the information professions should be careful not to reductively conflate terms, titles and professional commitments. Our rationale is informed by thinking of the traditional 'librarian' providing publicly available information to an arms-length client. This seemed to be the targeted audience for the IFLA code. A more expansive consideration of an information worker in a private setting may be more aligned with the data scientist. 
While IFLA's Code of Ethics for Librarians and Other Information Workers is permissive, the DSA's Data Science Code of Professional Conduct is cautionary. Ideally the discussion offered here will support the development, through an open task, of a more robust framework for library and information ethics and a more comprehensive and inclusive framework for thinking about and conceptualizing data ethics.

Prospective library and information students, information professionals and educators in the field and related fields should not conflate a data scientist's conduct framework with those of the librarians and other information workers. The implications of our analysis transcend an interest in data and extend into scholarship in the professions and labour studies. As well, implications of our findings have the potential to be infused into a critical contemporary global discourse of the knowledge economy and 'ways of knowing', currently heightened by post-truth realities, realities which increasingly indicate workplace speech and whistleblowing across industry sectors and fields need to be addressed. Analysis of codes of ethics alongside codes of conduct can benefit the endeavour. Ultimately a career can be made or lost in the critical decision to do or not to do (or say or share) something.

\section{Future Inquiry}

Looking ahead, while there continues to be acknowledgement of the role of ethics in the handling of data, and examples of ethical challenges, there is a lack of emergent and specific literature about codes of ethics or of the applicability of library and information (LIS) based ethical considerations to data science. For example, a search for 2016, 2017, and 2018 to date, literature, using the strings "data ethics" AND librar*, "data science” AND ethics, and "data scientist” AND ethics in Scopus, LISS, and LISA databases as well as in Google Scholar produced no tangible results. While waiting on new literature, there is a concrete development on a rhetorical level. The third draft of the 2018 rewrite of the Association for Computing Machinery (ACM)'s ACM Code of Ethics and Professional Conduct has been completed and merits exploration.

The first draft was notable because of the addition of "public good" as a primary ethical consideration in its preamble and within the code. By the third draft, the "public good" consideration was strengthened to "computing professionals must always support the public good" and moved to the first line of the preamble to provide emphasis to this "highest principle and main purpose of the Code." Other important changes as well bring it even closer into alignment with LIS based documents. First, the scope has been widened to include "all current and aspiring computing practitioners, instructors, influencers, and anyone who uses technology in a meaningful way" not strictly ACM members. (This mirrors librarianship, where there is no professional hurdle for members to be considered part of the profession.) ACM members are to encourage adherence by all computing professionals and have a duty to take action. Second, 
imperatives have now become principles through the use of 'should' rather than 'must/shall/will' language, with the intent that there is room for judgement in decisions. (This highlights a code of conduct vs. a code of ethics and prescription vs. aspirational.) Third, the legal focus has shifted to more of an ethically based focus for intellectual property rights. Furthermore, there is language that indicates there should not be unreasonable opposition of use of someone's own intellectual property for public good. (This underscores the paramount nature of public good considerations.) The polished code has a tentative publication date of July 1, 2018. Monitoring the ethos of this rhetoric is valuable for imagining future inquiry lines. 


\section{Reference List:}

American Library Association. (2009). Questions \& Answers on Enforcement of the Code of Ethics. Retrieved from http://www.ala.org/tools/ethics/faqenforcement [Accessed: 23/06/2017]

Association for Computing Machinery's Committee on Professional Ethics. (2017). Annotated diff between Draft 1 and Draft 2 of the 2018 Code. Retrieved from https://ethics.acm.org/wp-content/uploads/2017/04/Draft1-to-Draft2-diff.pdf?32ddaa [Accessed 18/01/2018]

Association for Computing Machinery's Committee on Professional Ethics. (2017). “Annotated diff between Draft 2 and Draft 3 of the 2018 Code". https://ethics.acm.org/wpcontent/uploads/2017/12/diff3.pdf?32ddaa [Accessed 18/01/2018]

Association for Computing Machinery’s Committee on Professional Ethics. (2017). Side-by-side Review of Code 2018 Draft 1 Changes. Retrieved from https://ethics.acm.org/wpcontent/uploads/2016/11/1992 and 2018Draft1 sidebyside.pdf?32ddaa. [Accessed $18 / 01 / 2018]$

Data Science Association. (2013). Data Science Code of Professional Conduct. Retrieved from http://www.datascienceassn.org/code-of-conduct.html [Accessed: 23/06/2017]

Floridi, L. \& Taddeo, M. (2016). What is data ethics? Phil.Trans. R.Soc.A374:20160360. http://dx.doi.org/10.1098/rsta.2016.0360 [Accessed: 23/06/2017]

International Federation of Library Associations and Institutions. (2012). IFLA Code of Ethics for Librarians and Other Information Workers. Retrieved from https://www.ifla.org/publications/node/11092 [Accessed: 23/06/2017]

Library and Archives Canada. Government of Canada. (2013). Library And Archives Canada, Code of Conduct: Values and Ethics. Retrieved from http://www.bac-lac.gc.ca/eng/aboutus/Pages/code-conduct-value-ethics.aspx [Accessed: 23/06/2017]

McGrath, P. (15 March 2013). Federal librarians fear being 'muzzled' under new code of conduct that stresses 'duty of loyalty' to the government. National Post. http://nationalpost.com/news/canada/library-and-archives-canada/wcm/c917869e-91854924-9b12-5b5b2849e70e [Accessed: 23/06/2017]

Shiri, Ali. (2014) "Making Sense of Big Data: A Facet Analysis Approach". Knowledge Organization, 41(5), pp. 357 - 368.

Sturges, Paul. (2009). Information Ethics in the Twenty First Century. Australian Academic \& Research Libraries, 40(4), 241-251. 


\section{Appendix A}

Table 2 provides a side-by-side comparison of the 2012 IFLA Code of Ethics for Librarians and Other Information Workers presented, in its entirety, with the 2013 Data Science Association Code of Professional Conduct Code slotted in where appropriate.

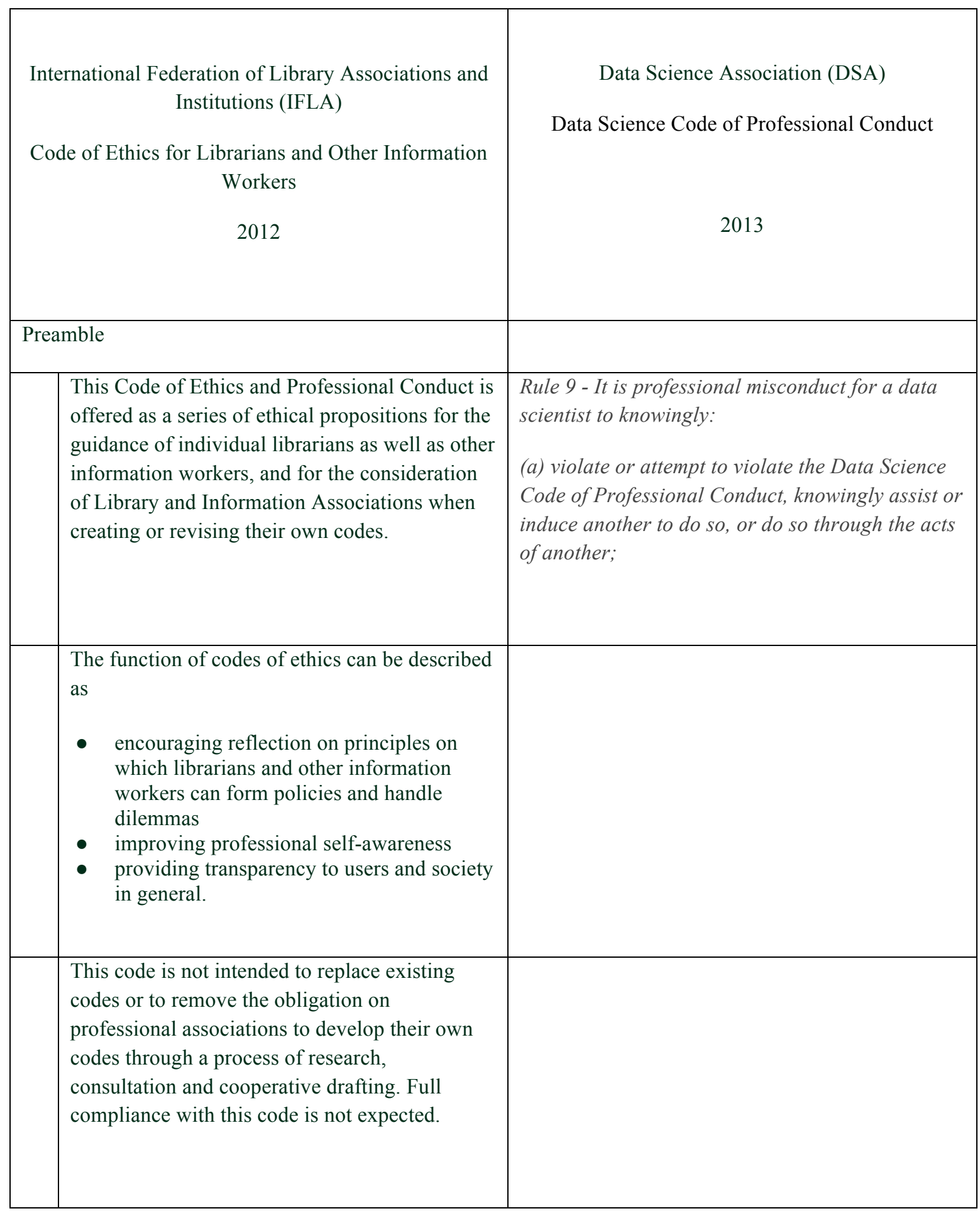




\begin{tabular}{|c|c|}
\hline This code is offered in the belief that: & \\
\hline $\begin{array}{l}\text { Librarianship is, in its very essence, an ethical } \\
\text { activity embodying a value-rich approach to } \\
\text { professional work with information. }\end{array}$ & \\
\hline $\begin{array}{l}\text { The need to share ideas and information has } \\
\text { grown more important with the increasing } \\
\text { complexity of society in recent centuries and } \\
\text { this provides a rationale for libraries and the } \\
\text { practice of librarianship. }\end{array}$ & \\
\hline $\begin{array}{l}\text { The role of information institutions and } \\
\text { professionals, including libraries and librarians, } \\
\text { in modern society is to support the optimisation } \\
\text { of the recording and representation of } \\
\text { information and to provide access to it. }\end{array}$ & \\
\hline $\begin{array}{l}\text { Information service in the interest of social, } \\
\text { cultural and economic well-being is at the heart } \\
\text { of librarianship and therefore librarians have } \\
\text { social responsibility. }\end{array}$ & \\
\hline $\begin{array}{l}\text { Furthermore, this belief in the human necessity } \\
\text { of sharing information and ideas implies the } \\
\text { recognition of information rights. The idea of } \\
\text { human rights, particularly as expressed in the } \\
\text { United Nations Universal Declaration of Human } \\
\text { Rights (1948), requires us all to recognise and } \\
\text { acknowledge the humanity of others and to } \\
\text { respect their rights. In particular, Article } 19 \text { sets } \\
\text { out rights of freedom of opinion, expression and } \\
\text { access to information for all human beings. }\end{array}$ & \\
\hline $\begin{array}{l}\text { Article } 19 \text { expressly sets out a right to "Seek, } \\
\text { receive and impart information and ideas in any } \\
\text { media and regardless of frontiers" which } \\
\text { provides a clear rationale for libraries and the } \\
\text { practice of modern and progressive } \\
\text { librarianship. IFLA in statements, manifestos } \\
\text { and policy and technical documents too } \\
\text { numerous to list has expanded the } \\
\text { understanding of work with information. } \\
\text { Implicit in this work is the idea of information }\end{array}$ & \\
\hline
\end{tabular}




\begin{tabular}{|c|c|}
\hline $\begin{array}{l}\text { rights and their significance for the profession } \\
\text { and society generally. The emphasis on } \\
\text { information rights in turn obliges librarians and } \\
\text { other information workers to develop a } \\
\text { principled critique of relevant law and to be } \\
\text { prepared to advise and, if appropriate, advocate } \\
\text { the improvement of both the substance and } \\
\text { administration of laws. }\end{array}$ & \\
\hline $\begin{array}{l}\text { The clauses of this code of ethics build on the } \\
\text { core principles outlined in this preamble to } \\
\text { provide a set of suggestions on the conduct of } \\
\text { professionals. IFLA recognises that whilst these } \\
\text { core principles should remain at the heart of any } \\
\text { such code, the specifics of codes will } \\
\text { necessarily vary according to the particular } \\
\text { society, community of practice or virtual } \\
\text { community. Code making is an essential } \\
\text { function of a professional association, just as } \\
\text { ethical reflection is a necessity for all } \\
\text { professionals. IFLA recommends the Code of } \\
\text { Ethics for IFLA to all its member associations } \\
\text { and institutions and to individual librarians and } \\
\text { information workers for these purposes. }\end{array}$ & \\
\hline $\begin{array}{l}\text { IFLA undertakes to revise this code whenever } \\
\text { appropriate. }\end{array}$ & \\
\hline \multicolumn{2}{|l|}{ 1. Access to information } \\
\hline $\begin{array}{l}\text { The core mission of librarians and other } \\
\text { information workers is to ensure access to } \\
\text { information for all for personal development, } \\
\text { education, cultural enrichment, leisure, } \\
\text { economic activity and informed participation in } \\
\text { and enhancement of democracy. }\end{array}$ & $\begin{array}{l}\text { Rule } 8 \text { - Data Science Evidence, Quality of Data } \\
\text { and Quality of Evidence } \\
\text { (a) A data scientist shall inform the client of all } \\
\text { data science results and material facts known to } \\
\text { the data scientist that will enable the client to } \\
\text { make informed decisions, whether or not the data } \\
\text { science evidence are adverse. }\end{array}$ \\
\hline $\begin{array}{l}\text { Librarians and other information workers reject } \\
\text { the denial and restriction of access to } \\
\text { information and ideas most particularly through } \\
\text { censorship whether by states, governments, or } \\
\text { religious or civil society institutions. }\end{array}$ & \\
\hline
\end{tabular}




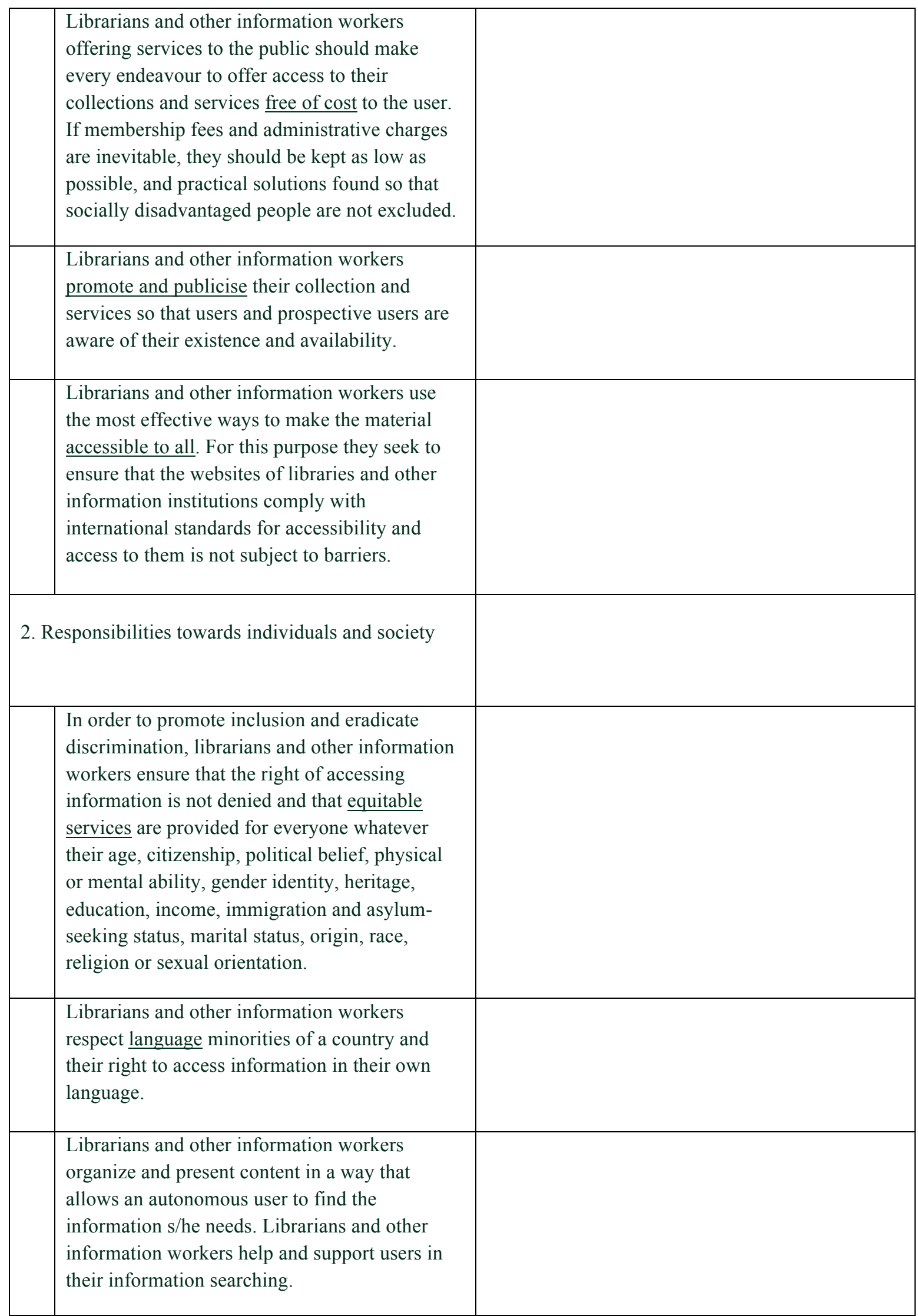




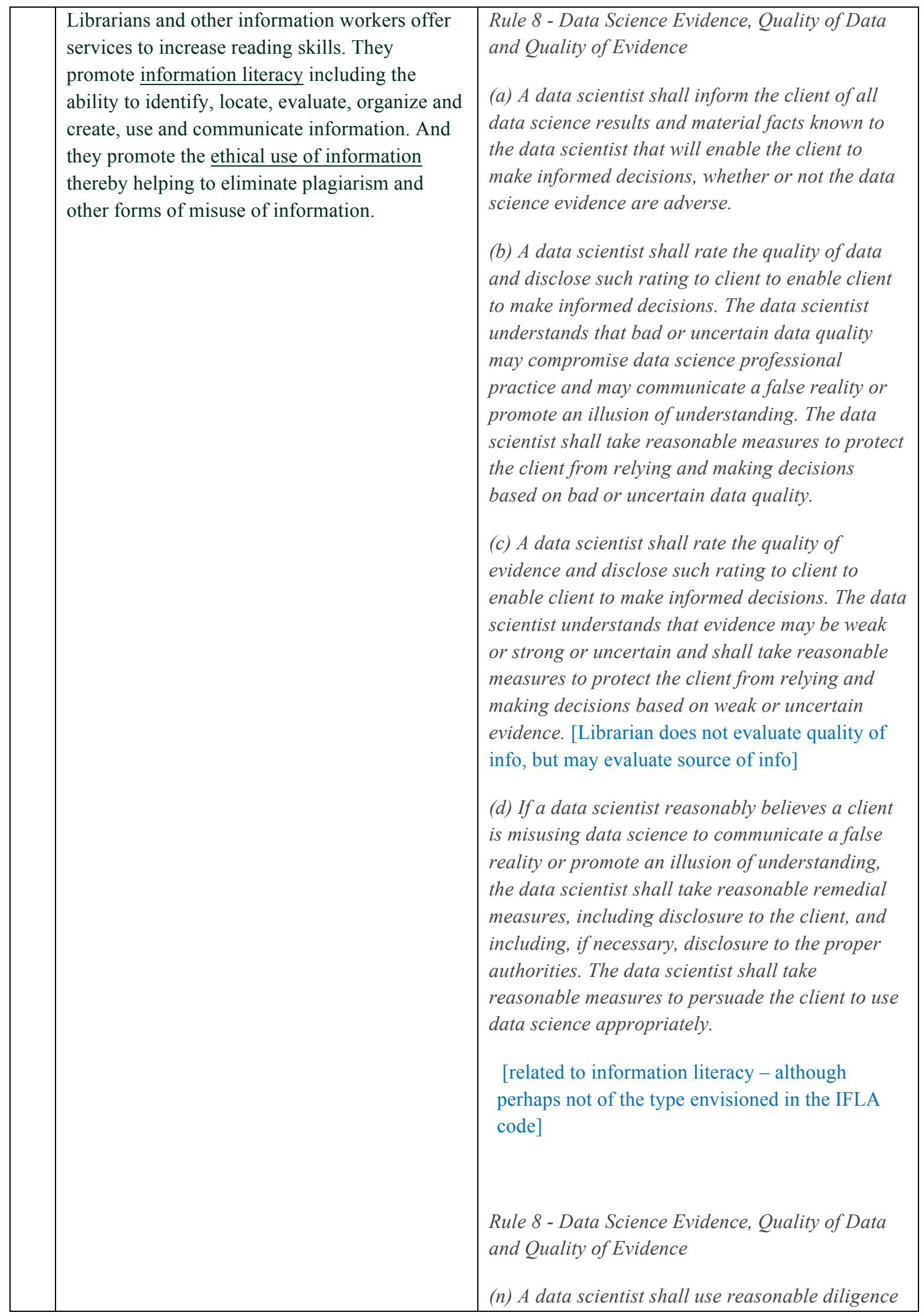




\begin{tabular}{|c|c|}
\hline & $\begin{array}{l}\text { to detect, recognize, disclose and factor real, } \\
\text { perceived and potentially hidden risks in using } \\
\text { data science. The prudent data scientist } \\
\text { understands that data creators and the designers } \\
\text { and builders of data management systems have } \\
\text { more knowledge than the data scientist and can } \\
\text { hide risks in the foundations and interpretations / } \\
\text { bias of the raw, created and manipulated data. } \\
\text { The data scientist shall take reasonable remedial } \\
\text { measures, including disclosure of risks to the } \\
\text { client. [related to information literacy] }\end{array}$ \\
\hline $\begin{array}{l}\text { Librarians and other information workers } \\
\text { respect the protection of minors while ensuring } \\
\text { this does not impact on the information rights of } \\
\text { adults. }\end{array}$ & \\
\hline \multicolumn{2}{|l|}{ 3. Privacy, secrecy and transparency } \\
\hline $\begin{array}{l}\text { Librarians and other information workers } \\
\text { respect personal privacy, and the protection of } \\
\text { personal data, necessarily shared between } \\
\text { individuals and institutions. }\end{array}$ & $\begin{array}{l}\text { Rule } 5(d) \text { A data scientist shall not reveal } \\
\text { information relating to the representation of a } \\
\text { client unless the client gives informed consent, the } \\
\text { disclosure is impliedly authorized in order to } \\
\text { carry out the representation or the disclosure is } \\
\text { permitted by paragraph (e). } \\
\text { Rule 5(f)(3) Communicating confidential } \\
\text { information only to client employees and } \\
\text { authorized agents (such as attorneys or external } \\
\text { auditors) who have a legitimate business reason to } \\
\text { know the information. }\end{array}$ \\
\hline $\begin{array}{l}\text { The relationship between the library and the } \\
\text { user is one of confidentiality and librarians and } \\
\text { other information workers will take appropriate } \\
\text { measures to ensure that user data is not shared } \\
\text { beyond the original transaction. }\end{array}$ & $\begin{array}{l}\text { Rule } 5 \text { (a) Confidential information is information } \\
\text { that the data scientist creates, develops, receives, } \\
\text { uses or learns in the course of employment as a } \\
\text { data scientist for a client, either working directly } \\
\text { in-house as an employee of an organization or as } \\
\text { an independent professional. It includes } \\
\text { information that is not generally known by the } \\
\text { public about the client, including client affiliates, } \\
\text { employees, customers or other parties with whom } \\
\text { the client has a relationship and who have an }\end{array}$ \\
\hline
\end{tabular}




\begin{tabular}{|c|c|}
\hline & $\begin{array}{l}\text { expectation of confidentiality. The data scientist } \\
\text { has a professional duty to protect all confidential } \\
\text { information, regardless of its form or format, from } \\
\text { the time of its creation or receipt until its } \\
\text { authorized disposal. [DSA clause broader than } \\
\text { IFLA in that it refers to the information content; } \\
\text { IFLA focused on information about the user] } \\
\text { Rule 5(h) A data scientist shall protect client } \\
\text { confidential information after termination of work } \\
\text { for the client. } \\
\text { Rule } 5 \text { (i) A data scientist shall return any and all } \\
\text { confidential information in possession or control } \\
\text { upon termination of the data scientist - client } \\
\text { relationship and, if requested, execute an affidavit } \\
\text { affirming compliance with obligations relating to } \\
\text { confidential information. } \\
\text { Rule 7(b) Even when no client-data scientist } \\
\text { relationship ensues, a data scientist who has } \\
\text { learned information from a prospective client } \\
\text { shall not use or reveal that information. }\end{array}$ \\
\hline $\begin{array}{l}\text { Librarians and other information workers } \\
\text { support and participate in transparency so that } \\
\text { the workings of government, administration and } \\
\text { business are opened to the scrutiny of the } \\
\text { general public. They also recognise that it is in } \\
\text { the public interest that misconduct, corruption } \\
\text { and crime be exposed by what constitute } \\
\text { breaches of confidentiality by so-called } \\
\text { 'whistleblowers'. }\end{array}$ & \\
\hline \multicolumn{2}{|l|}{ 4. Open access and intellectual property } \\
\hline $\begin{array}{l}\text { Librarians and other information workers' } \\
\text { interest is to provide the best possible access for } \\
\text { library users to information and ideas in any } \\
\text { media or format. This includes support for the } \\
\text { principles of open access, open source, and open } \\
\text { licenses. }\end{array}$ & \\
\hline
\end{tabular}




\begin{tabular}{|c|c|}
\hline $\begin{array}{l}\text { Librarians and other information workers aim to } \\
\text { provide fair, swift, economical and effective } \\
\text { access to information for users. }\end{array}$ & \\
\hline $\begin{array}{l}\text { Librarians and other information workers have a } \\
\text { professional duty to advocate for exceptions and } \\
\text { limitations to copyright restrictions for libraries. }\end{array}$ & \\
\hline $\begin{array}{l}\text { Librarians and other information workers are } \\
\text { partners of authors, publishers and other } \\
\text { creators of copyright protected } \\
\text { works. Librarians and other information } \\
\text { workers recognise the intellectual property right } \\
\text { of authors and other creators and will seek to } \\
\text { ensure that their rights are respected. }\end{array}$ & $\begin{array}{l}\text { Rule 3(b) A data scientist shall not counsel a } \\
\text { client to engage, or assist a client, in conduct that } \\
\text { the data scientist knows is criminal or fraudulent, } \\
\text { but a data scientist may discuss the consequences } \\
\text { of any proposed course of conduct with a client } \\
\text { and may counsel or assist a client to make a good } \\
\text { faith effort to determine the validity, scope, } \\
\text { meaning or application of the data science } \\
\text { provided. [DSA provision has much wider } \\
\text { application than this specific instance in IFLA] }\end{array}$ \\
\hline $\begin{array}{l}\text { Librarians and other information workers } \\
\text { negotiate the most favourable terms for access } \\
\text { to works on behalf of their users and seek to } \\
\text { ensure that access is not unnecessarily } \\
\text { prevented or hindered by the mode of } \\
\text { administration of intellectual property laws and } \\
\text { that licenses do not override exceptions for } \\
\text { libraries contained in national legislation. } \\
\text { Librarians and other information workers } \\
\text { encourage governments to establish an } \\
\text { intellectual property regime that appropriately } \\
\text { respects balance between the interests of } \\
\text { rightsholders and individuals and the institutions } \\
\text { such as libraries which serve them. }\end{array}$ & \\
\hline $\begin{array}{l}\text { Librarians and other information workers also } \\
\text { advocate that copyright terms should be limited } \\
\text { and that information that has fallen in the public } \\
\text { domain remains public and free. }\end{array}$ & \\
\hline \multicolumn{2}{|l|}{$\begin{array}{l}\text { 5. Neutrality, personal integrity and professional } \\
\text { skills }\end{array}$} \\
\hline $\begin{array}{l}\text { Librarians and other information workers are } \\
\text { strictly committed to neutrality and an unbiased } \\
\text { stance regarding collection, access and service. } \\
\text { Neutrality results in the most balanced } \\
\text { collection and the most balanced access to }\end{array}$ & \\
\hline
\end{tabular}




\begin{tabular}{|c|c|}
\hline information achievable. & \\
\hline $\begin{array}{l}\text { Librarians and other information workers define } \\
\text { and publish their policies for selection, } \\
\text { organisation, preservation, provision, and } \\
\text { dissemination of information. }\end{array}$ & \\
\hline $\begin{array}{l}\text { Librarians and other information workers } \\
\text { distinguish between their personal convictions } \\
\text { and professional duties. They do not advance } \\
\text { private interests or personal beliefs at the } \\
\text { expense of neutrality. }\end{array}$ & \\
\hline $\begin{array}{l}\text { Librarians and other information workers have } \\
\text { the right to free speech in the workplace } \\
\text { provided it does not infringe the principle of } \\
\text { neutrality towards users. }\end{array}$ & \\
\hline $\begin{array}{l}\text { Librarians and other information workers } \\
\text { counter corruption directly affecting } \\
\text { librarianship, as in the sourcing and supply of } \\
\text { library materials, appointments to library posts } \\
\text { and administration of library contracts and } \\
\text { finances. }\end{array}$ & \\
\hline $\begin{array}{l}\text { Librarians and other information workers strive } \\
\text { for excellence in the profession by maintaining } \\
\text { and enhancing their knowledge and skills. They } \\
\text { aim at the highest standards of service quality } \\
\text { and thus promote the positive reputation of the } \\
\text { profession. }\end{array}$ & $\begin{array}{l}\text { Rule } 2 \text { - Competence } \\
\text { A data scientist shall provide competent data } \\
\text { science professional services to a client. } \\
\text { Competent data science professional services } \\
\text { requires the knowledge, skill, thoroughness and } \\
\text { preparation reasonably necessary for the services. }\end{array}$ \\
\hline \multicolumn{2}{|l|}{ 6. Colleague and employer/employee relationship } \\
\hline $\begin{array}{l}\text { Librarians and other information workers treat } \\
\text { each other with fairness and respect. }\end{array}$ & \\
\hline $\begin{array}{l}\text { Librarians and other information workers } \\
\text { oppose discrimination in any aspect of } \\
\text { employment because of age, citizenship, } \\
\text { political belief, physical or mental ability, } \\
\text { gender, marital status, origin, race, religion or } \\
\text { sexual orientation. }\end{array}$ & \\
\hline
\end{tabular}




\begin{tabular}{|l|l|l|}
\hline $\begin{array}{l}\text { Librarians and other information workers } \\
\text { promote equal payment and benefits for men } \\
\text { and women holding comparable jobs. }\end{array}$ & \\
\hline $\begin{array}{l}\text { Librarians and other information workers share } \\
\text { their professional experience with colleagues } \\
\text { and they help and guide new professionals to } \\
\text { enter the professional community and develop } \\
\text { their skills. They contribute to the activities of } \\
\text { their professional association and participate in } \\
\text { research and publication on professional } \\
\text { matters. }\end{array}$ & \\
\hline $\begin{array}{l}\text { Librarians and other information workers strive } \\
\text { to earn a reputation and status based on their } \\
\text { professionalism and ethical behaviour. They do } \\
\text { not compete with colleagues by the use of unfair } \\
\text { methods. }\end{array}$ & \\
\hline
\end{tabular}

Table 2. IFLA code of ethics vs. DSA code of conduct 